\title{
Latin American 'free-trade unionism' and the cold War: an analysis based on educational policies
}

\section{Gabriela Scodeller}

To cite this article: Gabriela Scodeller (2017) Latin American 'free-trade unionism' and the cold War: an analysis based on educational policies, Labor History, 58:3, 327-349, DOI: 10.1080/0023656X.2017.1255539

To link to this article: http://dx.doi.org/10.1080/0023656X.2017.1255539

曲 Published online: 30 Nov 2016.

6 Submit your article to this journal 2

Џ Article views: 18

Q View related articles

View Crossmark data $₫$ 


\title{
Latin American 'free-trade unionism' and the cold War: an analysis based on educational policies
}

\author{
Gabriela Scodeller \\ Consejo Nacional de Investigaciones Científicas y Técnicas, Instituto de Investigaciones Gino Germani, \\ Universidad de Buenos Aires, Ciudad Autónoma de Buenos Aires, Argentina
}

\begin{abstract}
The political education of workers and their leaders was viewed as a strategic concern in the cold war period's bipolar world. This article discusses how this issue was dealt with by Latin American reformist trade unions grouped together in the Inter-American Regional Organization of Workers (ORIT, for its Spanish acronym), analyzing the educational policies promoted by its Inter-American Institute for Labor Studies (IIES), focusing specifically on its educational program for trade union instructors. We argue that the nature of the education provided changed, shifting from a rationale based on explicit ideological confrontation to a more focalized technical type of training. We claim that this shift started in the early 1960s, when the Alliance for Progress was launched.
\end{abstract}

\section{ARTICLE HISTORY}

Received 20 September 2015

Accepted 16 June 2016

\section{KEYWORDS}

Workers' education; Inter-American Regional Organization of Workers (ORIT); Latin America; Cold War

\section{Introduction}

The analysis of workers' political and union training bears overarching relevance, as it helps to understand how trade unions try to deepen or guide an action or conflict in specific directions; it also indicates the type of leaders, organizations, and workers to be shaped by every educational initiative, depending on historical moments, ideological traditions, and political influences. Yet, in the specific cold war setting serving as a backdrop to this study, this topic becomes even more significant as a result of the rising attention paid to it at the time. In fact, workers' training was considered strategic in that bipolar world, which is why several institutions with international reach (ranging from unions and governmental agencies to academic organizations) vied for this realm - and all of them grew more concerned about Latin America after the Cuban Revolution.

This article discusses how, against this backdrop, Latin American trade unions'leaderships planned the training of their members. As an initial approach to the subject, we will focus on the training policies promoted by the Inter-American Regional Organization of Workers (ORIT, for its Spanish acronym), an organization founded in 1951 and affiliated to the International Confederation of Free Trade Unions (ICFTU), which contributed to building and maintaining the social order shaped after World War II. ${ }^{1}$ The ORIT claimed to represent some seven million workers in Latin America, excluding members of affiliated organizations in Canada and the United States, who accounted for the bulk of its membership. 
In spite of the growing importance that workers' education acquired in those years, a review of existing literature reveals a historiographical gap around the topic, especially regarding the perspective of unionists themselves as the actors responsible for training processes. In addition, despite the diversity of groups and projects involved, the few existing studies concentrate almost exclusively on those who, due to their numerical and financial weight at ORIT, prevailed over their peers from the South - that is to say, the members of AFL-CIO's American Institute for Free Labor Development (AIFLD).

Thus, the Inter-American Institute for Labor Studies (Instituto Interamericano de Estudios Sindicales, IIES), as part of ORIT-ICFTU, is typically featured as an uncritical AIFLD appendage. The close ties that indeed existed between the AFL-CIO and the Latin American unions affiliated to ORIT, particularly concerning educational activities, have led to confusion between both institutions in the secondary literature, as these studies lack a scrutiny of IIES' specific training and teaching policies.

Analyzing the educational strategies fostered by the IIES, we will show that Latin American union leaders operated with relative autonomy from their Northern counterparts, acting in response to regional developments. As a result, the type of training offered by the organization to its members changed. This does not mean that the IIES stood against or resisted the influence or pressures coming from North American unionism. Rather, it suggests that Latin American union leaderships were not puppets but agents who consciously positioned themselves based on their tactical and strategic analyses. From this standpoint, the commonalities among them - which, in fact, were many - should be viewed as ideological matches. While this statement partly resembles ORIT's typical characterization in the secondary literature, this article will show how its commitment to the capitalist order was advanced by underscoring the socioeconomic aspects of training processes.

In fact, a review of the documents written between the 1950 s and 1970 s reveals two distinct stages. ${ }^{2}$ At first, ORIT's endeavors were characterized by a rationale of ideological confrontation against the so-called 'totalitarianisms', ${ }^{3}$ as well as by a quest to organize and disseminate its vision of 'free trade unionism' across the region. Instead, during the second period, ORIT prioritized a technical type of training, intended to prepare the labor force needed for Latin America's modernization process. Still politically oriented, this kind of education provided a new and much more efficient tactic to achieve the same strategic goal - maintaining the established order in a context of revolutionary threat. We will show that the beginning of this change came hand in hand with the launch of the Alliance for Progress (1961) 4 and that its specific effects on education became apparent some years later, by the mid-1960s.

This paper focuses on the second stage, as it contains major controversies between the sources consulted and the existing secondary literature. First, we will offer a brief description of the historical setting in which the Regional organization operated in order to clarify its positions and actions regarding workers' education. Next, we will describe the structure and activities carried out by ORIT-ICFTU's IIES - more precisely, its training program for trade union instructors, who were in charge of amplifying the guidelines of labor organizations back home. ${ }^{5}$ Before plunging into the topic itself, it is convenient to make a few remarks on our study field.

\section{Our subject and historiography}

The subject of workers' education can be located within a broader field of topics associated with the grasp of consciousness. ${ }^{6}$ Construed as an unfinished, contradictory, and ambivalent 
process, ${ }^{7}$ the grasp of consciousness effect is not unidirectional but can either subvert or preserve the established order. Indeed, this indeterminate outcome makes it relevant to explore the ways in which the dissemination of historical experiences, the reflection upon internal practices, or the learning from other groups and classes influence the results of such process.

Trade unions are, like other socialization loci, fundamental environments where meanings and knowledge are constructed and interpreted - that is to say that union undertakings mark key moments for participants' politicization processes. Thus, unions' educational activities, construed as propitious occasions to guide an action along various possible paths, become an important subject for the diverse ideological stances existing within the trade union movement, as well as for historical research.

We view trade union education as a field of conflict in itself: a realm where different traditions, ideologies, and practices confront each other, interact, negotiate, and combine. Our goal is to explore unionists' standpoint on the matter to understand the strategic outlines sketched in specific historical settings according to the political interests at stake, as well as the theoretical developments and pedagogical proposals that accompany them.

These educational practices become fully meaningful when they are analyzed with a relational approach, either in comparison with other contemporary experiences or by observing a single group's track record over time - for example, tracking the changes in the priorities awarded to educational policies, which sometimes leaned toward ideological matters while, at other junctures, shifted to technical and professional training, or union and labor rights issues. $^{8}$

Here, we will study unions' educational practices with the second approach. However, in order to plot our arguments within the more general background in which our story takes place, we should start by remembering that, in their eagerness to compete for the noncommunist Latin American workers, both the ORIT and its main counterpart, the Latin American Confederation of Christian Trade Unions (Confederación Latinoamericana de Sindicalistas Cristianos, CLASC-IFCTU), created dedicated institutes for educational tasks. The budget that the ORIT allocated to its Education Department rose from 5\% in 1952 to $18 \%$ in $1964,{ }^{9}$ while CLASC pledged $70 \%$ of its resources to train its leaders, activists, and members. ${ }^{10}$ In other words, trade union education held a prominent spot in the cold war setting and was viewed as highly important. As a result, it was the focus of dispute for union leaderships of different ideologies, according to their interests and strategic outlooks.

Nonetheless, as stated in the introduction, scant attention has been paid in the secondary literature to workers' education. In the studies about international trade union organizations, multiple aspects have been investigated, but, despite extensive historiographical production, ${ }^{11}$ the remarks on union training are merely tangential. Indeed, while disseminated data can be found on these organizations' educational endeavors, these analyses do not focus on teaching policies themselves but on unions or confederations as an institution. In turn, research studies on Latin American workers and their movements are equally prolific and have explored a vast array of issues, as proven by some of the most relevant review essays written over the past few decades. ${ }^{12}$ Yet, once again, an examination of the main works that have summarized their history ${ }^{13}$ reveals that the topic discussed here has not been included among the concerns explored by academics specializing on Latin America.

More specifically, the few studies about union education centering on Latin America concentrate, as noted earlier, on the AIFLD, while other experiences from the time have been 
overshadowed by or randomly assimilated into it. These studies have clearly demonstrated the links between the AIFLD and the United States' Central Intelligence Agency (CIA), the funding received from that country's government or from multinationals, as well as the blatant anti-communist content of its educational materials. ${ }^{14}$ In these studies, the AIFLD is nothing but one of the many imperialist attempts of the time to pursue ideological cooptation in Latin America - a scenario in which ORIT is typically and indistinctively included as a result of its close ties with the AFL-CIO. ${ }^{15}$

These interpretations bring forth a number of issues. First, while all of them agree on the importance of education during this period, because the AIFLD is treated mainly as a U.S. foreign policy instrument, these research works do not include a detailed study of pedagogical matters (apart from presenting data on the number of courses, participants, money invested, etc.). ${ }^{16}$ Second, as suggested earlier, the IIES' educational policies are incorporated into these studies without distinction, as clearly illustrated by Basurto Romero's research the only one specifically dedicated to analyze ORIT's institute, which states that 'the foundation of an institute in the image and likeness of the AIFLD is the most important achievement in this field thus far. ${ }^{17}$ Third, the Latin American trade union leaderships responsible for carrying these projects forward are characterized as puppets serving North Americans. Although framed in a wider context in which 'free trade unionism' is 'a consequence of the state of economic and political dependence that Latin America endures with respect to imperialism', this attitude is explained - not only but fundamentally - by union leaders' corruption and 'immorality'. ${ }^{18}$ In other words, this rationale portrays them as passive recipients of policies issued or strongly influenced by U.S. labor unions.

In this regard, a different interpretation - which challenges the existing links between ORIT and the AFL-CIO, showing their rifts - can be found in the articles referring to these organizations' activities in Brazil, Chile, and the Andean countries published in a recent book. ${ }^{19}$ The same perspective informs Rodríguez Garcia's highly detailed study of ORIT between 1949 and $1969 .{ }^{20}$ Our research is also influenced by a set of studies that view the cold war as a global phenomenon, granting agency and initiative to actors from the South. ${ }^{21}$

Along these lines, in the pages that follow, we will try to understand the interests that drove Latin American union leaders to design their own training programs. In the same way as U.S. labor leaders domination project was solely their own and not imposed to them by the White House or the $\mathrm{CIA}_{1}{ }^{22}$ we think it is time that the same agency is afforded to Latin American union leaders. This will contribute to overcoming the dichotomy that historiography has used to describe the latter either as 'victims' or as 'strong resisters' of U.S. labor imperialism. ${ }^{23}$ The understanding of their political choices does not make them kinder nor sympathetic but fully responsible for their actions and alignments.

\section{Education in context}

The changing priorities for ORIT's educational endeavors prove easier to understand when they are contextualized. The topic of this essay is permeated by the core concern of the second postwar period: the problem of development. Latin American reformist trade union leaders aspired to be part of its dynamics and designed their educational policies on that very basis.

We will therefore take a brief look at the reality that prompted the actions undertaken by ORIT in the field of education, but, first, it is necessary to characterize ORIT's leaderships. 
While much has been written about them, ${ }^{24}$ we think Rodriguez Garcia's definition contributes to the understanding of our topic. As she states, free trade unionists strongly defended the principles of individual freedom, political participation, private property, and equal opportunity; yet, what distinguished them was'a call for organized labor's active and well-defined participation in the planning and execution of projects aimed at the defense of liberal democracy and socio-economic development at home and abroad.25

Between the 1950s and 1980s, Latin America experienced a period of sustained growth, primarily fueled by the manufacturing sector. ${ }^{26}$ Despite industrialization process differences, it should be noted that the countries with greater representation in ORIT were Brazil and Mexico, followed by Colombia, Peru, and Venezuela. ${ }^{27}$ Among the larger countries with an early industrialization process, the first two were the ones that experienced the greatest economic growth between 1950 and 1980, increasing their industrial output almost 10 times. The remaining three are included within the group of medium-sized countries that embarked on industrialization through import substitution after World War II, achieving high manufacturing growth rates in the 1950s. ${ }^{28}$ These were the countries where productive structure changes were most acutely felt. Additionally, the Regional organization mainly gathered workers from blossoming economic sectors, like oil, gas, food, textiles, and automotive industries, among others. ${ }^{29}$

Despite Latin America's socioeconomic heterogeneity, these data offer a preliminary framework to gain a better understanding of ORIT's educational policy orientation: it needed to be up to date with the changing developments that were taking place or that were projected for the region. As a result, ORIT was keen on learning about the dynamics unfolding in advanced capitalist countries and securing the proper tools that would position it in a relevant place at the negotiating table.

However, while ORIT paid attention to the debates on the desired plans for labor process modernization and automation, its actual evolution in Latin America proved slow and limited. Instead, another problem advanced at great speed: Latin America's population grew at a high rate, as well as its economically active population, which also changed in composition. ${ }^{30}$ As noted below, far from being indifferent to this problem, ORIT devoted a great deal of time and specific efforts to it in the educational arena.

In short, the Regional organization tried not to remain on the sidelines of a complex and shifting environment and struggled for its place - as a strategic actor - in development planning processes. ${ }^{31}$ This is why ORIT endorsed and promoted Punta del Este Charter guidelines, viewed as an inter-American strategy that could solve regional socioeconomic problems, thereby blocking the spread of communism. Along the way, it continued to serve the logic and requirements of capital, providing technical skill training for the labor force wherever capital-intensive industries were developing and attempting to contain the ever-growing economically active population, which stood as an obstacle for the desired modernization process.

But what happened to the strictly ideological standpoint connected to the battle against communism, which historiography has stressed so much? As we will show, it became subsumed within the rationale described above. While there was no linear correspondence between the confrontational dynamics of Latin America's cold war and ORIT's educational concerns, it is useful to remember the different phases undergone in this period in order to have a clear picture of the landscape in which the Regional organization operated. 
Scholars agree that Latin America's cold war started when World War II came to an end, although its characteristics changed after the Cuban Revolution, ${ }^{32}$ which turned Latin America into a strategic territory within the global conflict. If, in overall terms, the United States' goal was to stop the spread of communism, in Latin America, it also involved reassuring American predominance over the region since the Soviet Union's relationship with Castro's regime was perceived as a clear intrusion into the U.S. 'own' territory. Nevertheless, the tension between both communist countries as a result of the way in which the Missile crisis was resolved soothed this old apprehension concerning extra-hemispheric incursions.

Now, considering broader social-political paths, it should be noted that rural guerilla experiences proliferated; governments emerged that - albeit not left-wing - were considered a threat to the interests of the United States, and a marked anti-imperialist and anti-North American feeling flourished among the southern populations. However, by the mid-1960s, White House officials seemed to realize that the specter of communism would not materialize in Latin America. On the one hand, the intensity of the confrontation with the Caribbean island had diminished as compared to the 1959-1962 period. On the other hand, the deployment of counterinsurgent activities, support for military coups, as well as territorial and political interventions in different parts of the continent ${ }^{33}$ had calmed the fear of an imminent (and multi-pronged) attack on U.S. power - so much so that, halfway through the decade, the Alliance for Progress itself lost vitality (due also to the meager results achieved by the program). ${ }^{34}$ Under Lyndon Johnson's administration, the focus of the cold war was no longer located in Latin America, which seemed relatively stable as compared to other regions around the world. The Vietnam War's renewed fierceness - as a result of the U.S. direct engagement - absorbed both U.S. attention and economic resources. ${ }^{35}$

These aspects mentioned above contribute to explain the shift in ORIT's educational policy. While primarily caused by social and economic developments, it overlapped with and was facilitated by a brief and specific period when the perception of revolutionary threat in the region began to quiet down. The words of a noted anti-communist and a representative of pro-U.S. trade unionism, Serafino Romualdi, during the 1966-1967 courses show this assessment on Latin America's situation:

Today, in light of the complete failure of the communist experiment in Cuba and the growing deficit and inefficiency of public services and basic nationalized industries, credited observers of the trade union scenario in Latin America agree that winds are blowing towards the acceptance of a modern concept of free enterprise adapted to every country's economic reality and political convenience inherent, in the predominant notion and in practice, to Latin American democracy. ${ }^{36}$

It should also be noted that the institutionalization of labor relations and the growth of both employment and wages created a 'relative labor peace' that lasted until the end of the 1960s. ${ }^{37}$ Also, through repression or proscription, most countries had weakened left-wing forces in trade unions, as well as the Confederation of Latin American Workers (Confederación de Trabajadores de América Latina, CTAL) affiliated to the World Federation of Trade Unions (WFTU). ${ }^{38}$

Nonetheless, shortly thereafter, starting the early 1970s, the alarm of revolutionary advancement in Latin America was renewed by a series of events: the 1969 Cordobazo in Argentina, the Chilean Popular Unity's triumph in 1970, the emergence of urban-armed organizations in the Southern Cone, and radicalized demonstrations by student, religious, cultural, and academic groups, among others. From one decade to the next, not only did 
labor unrest increase but, in many countries, it took a political turn to the left. This ThirdWorldism from below was compounded by a 'diplomatic activism' from above, intended to undermine U.S. supremacy in the region. ${ }^{39}$

In this new stage, as a result of its defeat in Vietnam and the financial crisis that followed, the United States changed its foreign policy toward Latin America, seeking more pragmatic solutions, such as the support for or planning of right-wing military coups - with a non-reductionist view of the domestic enemy. If, with Kennedy at the helm, economic development was expected to drive political stability in the region, with Johnson and even more so with Nixon, the poles of the equation would reverse. ${ }^{40}$ Even if ORIT's political attitudes supported this reactionary tone, they did not reflect directly on its educational policy.

We have summarized the conditions that led the anti-communist claim to become formally subsumed in ORIT's training, while retaining its content scaffolding. Perhaps it is important to point out that this did not imply the abandonment of its'anti-totalitarian' proclamations. What we want to highlight is that, in the new priorities established for educational matters, the latter went from being in the foreground of daily discourse to becoming a mere complement. This seemed to be a much more effective approach to sustaining a capital-labor relation model which, as known, pursued cross- class collaboration, free competition, and individual profit. In this regard, if the Alliance for Progress is viewed as blending the cultural sense of 'generic developmentism'41 of the time, it is conceivable that Latin American leaderships were more likely to accept its principles than the North American union cadres. In accordance with their assessment of the continental reality, they incorporated the socioeconomic argument more easily as an instrument to fight communism, while the latter were much more elusive to moderate their openly anti-communist preaching.

\section{The construction of an educational structure}

ORIT's educational activities intensified toward the mid-1950s. From its foundation and with S. Romualdi as Education Director, several courses were organized at the University of Puerto Rico's Labor Relations Institute, which was created with strong support from the Regional organization. ${ }^{42}$ In 1954, the Inter-American Seminars began, merging as of 1956 with the international ones, organized jointly with ICFTU.

In 1962, the creation of the Inter-American Institute for Labor Studies (IIES) marked a qualitative and quantitative leap forward. Since 1966, it featured its own building, located in Cuernavaca, Mexico, while previously its activities were held at the Confederation of Mexican Workers' (CTM) headquarters in Mexico City. ${ }^{43}$ The funding for the construction of the building came primarily from the ICFTU's International Solidarity Fund, which was also the main economic sponsor of the institute's activities over the years. ${ }^{44}$

Considering that 'the formation and training of trade union instructors is a central task in order to fulfill the revolutionary mission of free and democratic unionism, ${ }^{\prime 45}$ since its inception and over the years, the Institute focused on training trainers as a priority via its 'Ordinary Courses for Trade Union Instructors'. In order to disseminate the topics and perspectives studied there, national or local unions were required to organize educational activities coordinated by the member who had participated in such courses. ${ }^{46}$ When the 6 th Course began (June-August 1964), Oscar Recabarren, acting IIES Director at the time, summarized these goals as follows: 
The ORIT is determined to create a great legion of Instructors that have and will have the task of training many others in their own countries of origin; as a result, a great chain will be forged, with comrades attending these Courses as its links. ${ }^{47}$

Initially, these courses lasted two months and were offered at least twice a year. Every course was attended by 20 to 30 trade unionists from several Latin American countries and a diversity of sectors. Their ages ranged from 25 to 45 , and most had four to nine years of union experience. It is worth pointing out that course attendees served in some leading capacity at their respective unions and that they were always men. ${ }^{48}$

In addition, the Institute offered inter-American or regional seminars specialized in a particular subject, branch of activity, population segment (women, youth, rural workers, etc.), or internal department (press, organization, etc.), which were usually organized jointly with another body, such as international federations and inter-governmental organizations. It also contributed to the events carried out by its affiliates. While grass-roots workers and activists took part in local activities, those arranged at a regional or international level were aimed at leaders from higher ranks.

Such range of activities required exchanging opinions and working together with a variety of union, intergovernmental, or academic institutions, depending on the topics addressed and the technical expertise each could contribute. As a result, a number of political-pedagogical orientations coexisted at IIES, and their respective nuances should not be underestimated, although their concerns and interests were closely related. Some ties were more permanent than others. Indeed, the relationship with AIFLD was more systematic, as a result of the coordination of educational events carried out by AIFLD in Latin American countries. Many graduates from these local courses continued their training at the institute's headquarters in the United States, where six-week seminars were delivered five times a year. ${ }^{49}$

Earlier studies have shown the strong influence of the AFL-CIO and, particularly, of the AIFLD on ORIT. ${ }^{50}$ However, the simultaneous launch of two institutes that were initially intended to deal with the same educational tasks is in itself a fact that draws attention to possible differences between them. ${ }^{51}$ If any sort of competition existed, the AIFLD's economic support enabled it to perform its activities far beyond the reach of IIES. ${ }^{52}$ It should be noted that U.S. unionism's continuous efforts to influence its Southern partners grew in the wake of the Cuban Revolution and increased still further with the funding received from the Agency for International Development (AID) thru the Alliance for Progress. ${ }^{53}$

The IIES went through a critical period - a partly financial, partly political crisis - that started in the early 1970s and was caused by the clashes between ICFTU and AFL-CIO, with ORIT caught in the crossfire. Even though the IIES was founded by ICFTU (along with its colleges in Calcutta and Kampala), the influence of U.S. unionism on the institute was, as mentioned, significant. These tensions heightened when the AFL-CIO withdrew from ICFTU but stayed on at ORIT, even holding key places there. ${ }^{54}$ After that, ICFTU played a much more active role in the Institute, driving some changes in the institution's front-line staff and in the alliances forged with other educational centers. Nevertheless, due to the persistent problems besieging the IIES in those years, in late 1976, it was decided that the courses would be held directly in the Latin American countries with the affiliated unions, following the pattern ICFTU had established for Africa and Asia. 


\section{Redefining educational policies}

First the Cuban Revolution and then the Alliance for Progress raised the problem of the region's underdevelopment in the agenda, clearly posing the solutions as either social revolution or reform. ORIT fully engaged itself in the debates around the issue of development, with a clear commitment to the 'peaceful revolution' ${ }^{\prime 55}$ policy. This meant discussing topics like democracy promotion, regional economic integration, agrarian reform, industrialization process, and population growth, among others. ${ }^{56}$ The ORIT's analysis of such issues in the Latin American context varied, as illustrated by discussions over industrialization, technology, and the kind of workforce required by the modernization process. As mentioned, while ORIT was originally interested in promoting labor process automation, over the years, it became increasingly concerned about the 'demographic explosion' issue, given its consequences for the region's development process.

In such context plagued by concerns and debates, ORIT outlined its educational policies. Whereas until 1962 all emphasis had been placed on 'trade union training' over'professional or technical training' or 'basic or cultural education' - spheres in which unions could participate but that belonged in the governmental sphere of responsibility ${ }^{57}$ - contents related to the region's modernization gained strength, more often than not explicitly framed within ALPRO's aims. ${ }^{58}$ Thus, between the two Inter-American Economic and Social Conferences organized by ORIT in 1961 and 1967, respectively, the 'economic and social development' issue was placed on the agenda and began to be considered in terms of educational policies.

Initially, the Regional organization trained its own cadres in economic and labor issues. Already by mid-1962, Secretary General Arturo Jauregui Hurtado noted that they were'making great efforts to form worker-economists who can collaborate with governments and international organizations. ${ }^{59}$ In January 1964, motivated by the labor movement's growing concern for workers' education arising from the 'accelerated progress of industrial development in all countries and the growing role and responsibilities of unions ${ }^{\prime 60}$, ORIT held its First Inter-American Conference of Labor Education Directors. It is worth mentioning that prior to this meeting, the interim head of the Labor Relations Program carried out by the Organization of American States' (OAS) Social Affairs department, Valerio Agostinone, communicated ORIT's Assistant Secretary General Morris Paladino that his organization was interested in promoting 'education for development'. In his letter, he also emphasized the importance of prioritizing economic issues, thus revealing that engagement with training labor cadres for development was not one-sided. ${ }^{61}$

A year later, this inclination, as well as its two-sided nature, became clearly visible during ORIT's Sixth Continental Congress. In relation to labor, the gathering recommended to'elaborate specialized programs covering topics such as automation, mechanical technology and industrial economy'. With respect to a broader social-economic level, the importance of 'subjects linked to housing programs, cooperatives, labor statistics and planning techniques'62 was asserted. Later, ORIT's Second Inter-American Conference of Trade Union Education Directors and Experts defined the political meaning of changes previously implemented in terms of concrete curriculum content. It highlighted the importance of introducing themes meant to improve'the economic, political, social and cultural functions of trade unionism in democratic societies' within what had been the 'core of traditional union education. ${ }^{63}$ Closing remarks at the meeting suggested the reasons for moving in such direction. 
Union education on the economic development of modern society must prepare leaders that can fully and effectively participate in planning and executing plans aimed at achieving greater industrial and agricultural productivity, thus increasing the purchasing power of workers. This constructive role of unionism demands an intensive educational effort to extend the horizons of trade union goals in the world today. The trade union movement, in order to fulfill its obligations towards workers and their respective nations, requires trained and responsible leaders who must be aware of the complex problems demanding solution. ${ }^{64}$

Already in what was called the second development decade, in March 1970, the Seventh Continental Congress decided to give'greater emphasis to demography, planning and family well-being, etc. in educational and informational activities, with the purpose of raising awareness among militants about dimensions and consequences of the accelerated growth of the Latin American population'.65 Thus, we can see how the initial concern for'development planning' extended as far as to include matters related not only to production but also to the sphere of reproduction. In fact, designing educational programs in tune with different historical moments was a central characteristic of ORIT's policies.

As shown, changes accompanied the Regional organization's analysis of the context in which its actions took place. It went from being concerned with debates coming from capitalist advanced countries and interested in the professional training of a specialized labor force to considering other issues linked to full employment and a labor-intensive based kind of development, which implied a strong tendency toward vocational training (i.e. less specialized but more comprehensive in numerical terms) ${ }^{66}$ In short, far from being rigid, ORIT's positions varied as a result of the diverse and dynamic discussions they nourished from and of the way in which projected economic and social developments took shape. Thus, it slowly gave up its desired automation goal to attend to the region's more real and urgent needs.

\section{IIES' educational programs}

Next, we will analyze how the general guidelines presented in the previous section translated into educational programs. We will look at the Courses for Trade Union Instructors. As stated at the beginning of this article, ORIT's worker educational policies featured two stages. During the first one - from its inception to the beginning of the 1960s - focus was placed on trying to spread the organization's ideological perspective. This can be explained by the cold war context and the need to strengthen a collective identity. Hence, educational activities aimed

to train members of the democratic union movement to manage existing unions and to organize them where they do not exist, to provide basic cultural elements that will guide members in their duties and labor studies and to encourage them to defend free trade unionism in the face of the destructive tactics of totalitarianism. ${ }^{67}$

During the second stage, dominant concerns would not be posed in terms of open ideological confrontation against communism, but of the pursuit of technical training to achieve 'economic and social development'. As we will see, this trend involved a slow process, not free of fluctuations and contradictions, both due to changing context conditions and to the coexistence within ORIT of diverse theoretical perspectives. ${ }^{68}$

As we have already suggested, existing literature has only paid attention to the first aspect, establishing a continuum that does not distinguish nuances or changes in ORIT's educational policies. In other words, models and strategies designed during the first part of the second postwar period are projected into the second, when the context was substantially transformed as a result of the Cuban Revolution. In addition, it loses sight of the fact that reformist 
Latin leaders, driven by their own belief and even before their North American counterparts, were the ones to embrace the idea that shaped and gave meaning to ALPRO: that the battle against communism in the region was not (only) an ideological struggle but had to be fought (fundamentally) on an economic and social front.

Upon analyzing the courses for trade union instructors implemented by IIES since 1962, it is evident that the anti-communist discourse had very gradually come to occupy secondary position. These courses were at the heart of ORIT's training policy, and they were also the most common and regularly offered programs. We will describe the initial scheme as well as the most significant modifications it experienced over the years. At the same time, we will consider opinions provided by attendees in order to appreciate which contents were emphasized or aroused greatest interest. ${ }^{69}$ In other words, we will see the practical effects of what was theoretically desired or projected through curriculum planning.

From the start, subjects were grouped into three broad areas. The 'Orientation' area was in turn subdivided into two parts: 'Economic and Social Problems' and 'Political Problems'. The former included all socioeconomic aspects related to regional development problems and featured classes on Economy and Industrialization, Agrarian Problems, Productivity, Automation, Task Assessment, Social Security and Housing, and Cooperatives. The latter discussed strictly ideological topics under the axis 'totalitarianism versus democracy', specially denouncing communism - mostly exemplified by the Cuban case. Topics included Democracy; Latin American Dictatorships; Militarism; Popular, Intellectual, and Student movements; Imperialism; and Communist Tactics. In addition, there were also classes devoted to the history of the international labor movement and its organizations, and to different international institutions and agencies, such as the International Labor Organization (ILO), the OAS, the United Nations (UN), and ALPRO.

It is interesting to point out that while 10 sessions were assigned to themes within'Political Problems', there were 23 included in 'Economic and Social Problems'. However, it is important to contrast these data in terms of the amount of hours in the timetable dedicated to each thematic area with the emphasis that both teachers and students placed on contents. A Mexican delegate who attended the 4th Trainers' Course held in late 1963 commented on the most compelling classes:

1st The Alliance for Progress, which is an agreement signed by all Latin American governments to free our continent from hunger, misery, illiteracy and tyranny... 2nd The most interesting class revolved around the study of democracies that are against communism, and Capitalism, from extreme to right-wing. ${ }^{70}$

Also, in their evaluation of the same course, a group of three Argentinian participants emphasized the knowledge acquired through topics covered in 'Political Problems':

These classes helped us to completely understand the underhand methods used by communists to achieve trade union leadership and lead the working class to engage in actions that may damage workers, with the only aim of intentionally provoking social resentment and thus prove that democratic regimes are obstacles to progress and social wellbeing. Aware of the methods and techniques employed by these servants of Soviet imperialism, workers' leaders are fully conscious that allowing these regimented automatons to act within the workers' movement can bring disastrous consequences to the working class. In addition, they are properly prepared to combat them and prevent this social cancer from taking root and hindering the true evolution of the movement that, slowly but surely, is taking the working class along the road towards democracy, liberty and social justice. ${ }^{71}$ 
Compared to such a strong statement, their report paid less attention to topics under 'Economic and Social Problems', offering some general comments on cooperatives, the agrarian reform, and unions' responsibilities in 'planning, production, industrialization, distribution and consumption processes, so as to enable a better distribution of goods. ${ }^{72}$

In other words, both cases show that students' reception of the contents delivered was still focused on ideological issues. On the other hand, from an institutional angle, economic and social matters vital to the Punta del Este Charter had yet to become predominant. As it were, ideological and socioeconomic concerns ranked equally, as seen in the text describing these courses:

The aim is to give the participants background knowledge in the principles and processes of democracy, the methods of infiltration and subversion by totalitarians, the principles and nature of a good agrarian program, problems of productivity (including time studies and piece rate setting), study of financial reports, principles and organization of cooperatives and of housing programs. ${ }^{73}$

The second set of classes, grouped under the 'Workers' Education' area, constituted the fundamental part of the syllabus. It was practical-theoretical in focus and consisted of 95 sessions. Strictly pedagogical aspects were covered under topics such as Adult Education, Teaching Methods and Techniques, Group Discussions, and Use of Audiovisual Material, and took up 67 sessions. Other classes handled matters more directly linked to organizational duties, preparing attendees to'plan educational programs' on legislation, collective bargaining, organization, managing assemblies, etc. (28 sessions).

Finally, a third area called 'Aspects of General Culture' provided journalistic and public speaking tools, offered lectures and round tables on contemporary issues (delivered by trade unionists or members of international institutions), and organized visits to Mexican factories or cooperatives. ${ }^{74}$

Summarizing, there was a set of pedagogical - both practical and theoretical - classes, as well as classes of ideological nature, others which provided tools for socioeconomic analysis, and yet others focusing on labor and union issues. That is to say, the program covered a broad range of subject matters, which had to be understood in depth so that future instructors could carry out their tasks effectively. So far, discussions around development as way of preparation to play an active role in it evolved among the highest cadre of the organization, not so much at this intermediate level of leaders, whose training continued to be more general. Topics related to the region's economic and social development held no central position in the syllabus, but served as an aid to understand the context in which union militants were acting.

However, this changed from the second half of the 1960s onwards. The 8th Course (February-April 1966), the first one held at the Institute's building at Cuernavaca, was 'conceived as an advanced program with very little emphasis on basic subjects.'This adjustment was introduced based on the fact that now 'there were already so many fine national trade union training centers throughout the hemisphere which offered splendid courses on basic trade union subjects.' ${ }^{75}$ Therefore, IIES meetings could be considered a valuable opportunity to delve deeper into more specific economic and social issues.

In fact, a year later, course content emphasis shifted. At the end of the 11 th Course, Basilio González Hermosilla, IIES Assistant head and Program director noted,

Brothers who graduate today as union instructors have looked into and studied about collective agreements, trade union journalism, adult education, public speaking, the history of 
international trade unionism, labor legislation and, fundamentally, everything related to economic and social development of our continent. And that is because today, more than ever, trade unionism and its leaders in our continent are forced to occupy a vanguard position in the vigorous effort of Latin America to achieve a rapid economic, social, cultural and political advance in the region. ${ }^{76}$

Thus, by 1968, the ordinary course devoted 68 hours to topics covered under 'Economic and Social Development', and 12 to those under 'Political Doctrines'. The former included modules on Principles and Foundations of Economics; Programs for Latin American Integration; Comparative Social security; Health and Safety at Work; Productivity; Community Development; Agrarian Reform; Human Relations; The role of Trade Unionism in the Alliance for Progress; Cooperativism; Cooperatives in Mexico; and Cooperatives in Israel. The latter comprised: Socio-political Tendencies; Political parties and the Union Movement; and Dictatorship and Democracy in Latin America. ${ }^{77}$

Over the years, this concern with 'economic and social development' themes also stood out in newspapers created by students as class assignment for the 'Trade Union Journalism' course. Along with descriptive articles about activities at the Institute, participants wrote opinion pieces on different subjects studied. The regional integration process or the agrarian reform was now a trending topic, while comments about political systems became marginal - unlike the reports of the 4th Course four years earlier. In turn, these articles were not focused on criticizing communism but rather on praising democracy - against dictatorships (communism included) - as the only political model under which development processes could proceed.

For example, in the organization's periodical entitled Vanguardia de ORIT, 11th course attendees reflected upon the importance of training linked to their demand for labor participation in economic and social development processes. Thus, the editorial section reported:

Nowadays, nobody can deny that education is a factor that accelerates economic development, and the labor movement knows that the responsibility it is asking to share in this development can only be entrusted to men with a good and broad cultural, technical and, wherever possible, scientific, preparation. ${ }^{78}$

In their Solidaridad publication, the 14th course participants tackled the following topics: regional economic integration; agrarian reform; community development linked to the problem of population growth; apprenticeships connected to manufacturing changes, especially mechanization; and omission of international agreements that placed trade union participation on the agenda of development programs. A Peruvian attendee summarized some of these ideas:

The changing world in which we are living forces us to seriously ponder upon the constant industrial evolution, the complexity of economy in general and the pressing need for trade union movements in countries on the path to development to strengthen their leadership cadres with specialists in these matters. In order to fulfill their role in the most effective and organized manner to contribute to development plans in their respective countries, leaders must have the necessary qualifications in this field.... The larger the number of trained leaders-workers, the easier it will be to perform the task imposed upon us by the inevitable process of industrial evolution and automation that demands the engagement of workers adequately trained in economic and social matters. ${ }^{79}$

These comments reveal that students adopted the core principle behind the 'peaceful revolution': in order to assist the longed-for process of regional development, specialized technical knowledge of socioeconomic matters was required. 
This tendency was further deepened as of midway 1968 when courses were centered on specific topics. Hence, the 15th Ordinary Specialized Course (June-July 1968) jointly organized with ILO dealt with 'Development and Integration Problems in Latin America', as did number 19 (July-August 1969), coordinated with the Inter-American Development Bank (IDB). ${ }^{80}$ Again, during the opening of the first of the above-mentioned courses, IIES Program director explained:

It will be aimed at analyzing, in the broadest way possible, the role that workers must play in integration programs and economic and social development planning. We hope that this Course, and in particular its participants, will manage to elucidate the best way for workers to participate in such processes. ${ }^{81}$

It is remarkable how this theme was most rigorously examined throughout the courses. Both the 15th and 16th courses were divided into four cycles, preceded by a preparatory week designed to deliver a general political introduction to the topic, ${ }^{82}$ and to offer some notions of statistics as economic theory concepts. The first two cycles were similar for both courses. The first one was called 'Planning' and encompassed the study of policy-making, ECLA projections, planning experiences in other regions, different integration plans, sector planning (in agriculture and industry), multiplier effects of industrialization, and State roles. The second cycle, entitled 'Economic Development', analyzed problems of developing countries, growth policies, national and international economic inequality mechanisms, under-development causes, investment plan priorities, international collaboration, and international trade. ${ }^{83}$

The 15th Course's third cycle approached the issue of 'Labor Economics' and featured subjects such as human resource planning and employment policies for economic development, among others. The final cycle, entitled 'Political theories, Social sciences', included debates on Latin American society, social and economic regional integration, international inequalities, absence of a continental ideology, and land tenancy. On the other hand, the 19th Course's third cycle was centered on discussing the 'Sociological Aspects of Integration', while the fourth dealt with its legal, political, and philosophical implications, including subjects like 'Under-Development and Dependency'.

We should call attention to the fact that involvement of experts from international organizations in these events became increasingly significant. For example, out of the 22 tutors who participated in the 15th Course, 14 were specialists from organizations like ILO, ECLA, the Latin American Institute for Economic and Social Planning (ILPES, by its acronym in Spanish), IDB, and the Institute for the Integration of Latin America and the Caribbean (INTAL, for its acronym in Spanish), among others. Academics from the College of Mexico and the Latin American Faculty of Social Sciences (FLACSO, for its acronym in Spanish) also joined the courses. Not only did they have the technical knowledge that Latin American union leaders demanded but the alleged neutrality attributed to their discourse reinforced the orientation that ORIT tried to imprint on its training processes.

As a consequence, toward the end of the decade, there was no doubting the direction in which ORIT's educational concerns were headed. Furthermore, while these socioeconomic contents were reinforced, strictly didactic subjects were losing ground. The pedagogical imprint that had characterized the courses for trade union instructors at inception had gradually faded. Over the years, with courses being shorter in time and limited to narrower themes, training had also ceased providing future trainers with a comprehensive background. ${ }^{84}$ 
Finally, it is worth mentioning the seminars organized by ORIT's Population and Work Unit. ${ }^{85}$ Within the context of the organization's concern with regional development, worries about the'demographic growth within development and integration plans' 86 emerged. The matter was evaluated at various meetings from the end of 1967 onwards, becoming systematically addressed in educational activities since 1970. Defining 'Family Planning' as a solution to this problem and as a'human right', ORIT sought to 'improve the quality of workers' families' $^{\prime 87}$ through this education program.

Most of the seminars promoted ${ }^{88}$ by the Population and Work Unit hinged on three main areas: 'Demography,' 'Family Planning' and 'Communication in Family Planning'. The first area covered topics such as population of Latin America; demographic trends in each country; sociocultural factors that favored population growth; population and economic development; workforce; employment and unemployment; wages; and family and society. The second area was related to the study of human anatomy and physiology of the reproductive system; sexual education; contraceptive methods; and family planning and responsible parenting. The third area dealt with communication theory applied to family planning; development of audiovisual materials; use of mass media; communication and information; and advertising. ${ }^{89}$ Just as the courses for trade union instructors, these seminars were conceived with a clear broadening purpose. Target groups included education heads, women, young people, and rural sectors. The idea was to have these themes integrated into national or local educational programs, thus responding to the guidelines laid down at the Seventh Continental Congress in 1970.

\section{Education for capital}

In the midst of cold war bipolarity, the few historiographical references to trade union education during this period usually remained limited to the terrain of ideological indoctrination. Contrary to this line of interpretation, we have argued that ORIT's interest in maintaining the capitalist order of things was not reduced to a battle on the symbolic-discursive level - aspect emphasized in the secondary literature - but had a tangible side that was visible in Latin American reformist union leaders' concern for taking workers' education into their own hands.

Throughout the research, we discovered leaderships that, during the 1960s, became increasingly attentive to performing an active role in the socioeconomic development process projected for the region and which translated into the educational policies they promoted. In this regard, sources consulted as the selected thematic approach revealed new insights into an old debate.

Firstly, this paper has shown that the nature of the training ORIT imparted to its members underwent a transition. The initial emphasis placed on contents that denounced 'totalitarian' political systems gave way to a focus on technical aspects. Accompanied by a 'neutral' language - that of experts from intergovernmental organizations - this turned out to be a much more efficient approach to guarantee both the kind of labor force that capital required as well as control over excess population.

Secondly, we stated that this change in ORIT's educational priorities accompanied the launch of the Alliance for Progress, understood as an Inter-American scheme to hold back communism in the region and as a strategy to channel the revolution/reform dilemma through social and economic - rather than explicitly ideological - paths. ORIT adopted this 
direction even more willingly than its Northern counterparts, on the basis of its understanding of the regional context. If there were tactical and strategic coincidences between them, it was not because Latin America trade union leaderships were uncritical puppets of Northern leaderships, but because they were both part of the same reformist horizon.

Finally, and without ignoring the historic confrontational framework in which these training programs evolved, it is our understanding that, in the long run, they represented a turning point in the sense that they went beyond the battle against communism and contributed to establish a 'modern' model of business unionism in Latin America that outlived the cold war.

\section{Notes}

1. For more on ORIT and its predecessor, the Inter-American Confederation of Workers (Confederación Interamericana de Trabajadores - CIT), as for other international labor organizations operating in Latin America during the twentieth century, see Godio and Wachendorfer, "Las internacionales sindicales"; and Alexander, International Labor Organizations. For a comparative study of ORIT with its European counterpart, see Rodríguez García, Liberal Workers of.

2. The archival research that this paper is based on was conducted thanks to a grant from the International Institute of Social History (IISH) in Amsterdam. The primary sources cited correspond to this collection (referred to herein as ICFTU Archives - IISH). Unless stated otherwise, all the mentioned documents were originally written in Spanish.

3. Even if explicitly against communism, any group or movement that questioned U.S. interests in the region was included into this category.

4. We do not regard the Alliance for Progress (ALPRO) as a unilateral strategy of U.S. foreign policy but as a strategic horizon that - albeit with tensions - managed to gather shared interests. Despite the nuances in assessments or programs to be implemented, the ideas on modernization and development circulating since the early 1950s merged into a structured and homogeneous policy for the region with the guidelines and recommendations set forth in the Punta del Este Charter, which outlined ALPRO's objectives and was named after the city where the meeting took place.

5. Therefore, the paper excludes comments on educational activities intended for national or local unions' rank and file, as well as training for cadres with leadership roles.

6. Piaget, La toma de.

7. Mergner, Social Limits to.

8. While all of them are political by definition, for analytical purposes, it is important to differentiate among these different types of training.

9. Rodríguez García, Liberal Workers of, 96.

10. Alexander, International Labor Organizations, 210-1 and 224.

11. Godio and Wachendorfer, "Las internacionales sindicales"; Parcero, La CGTy; Carew et al., The International Confederation; Heerma van Voss et al., Between Cross and; Alexander, International Labor Organizations; Rodríguez García, Liberal Workers of; van Daele et al., ILO Histories. Essays, and Walters Jr. and van Goethem, American Labor's Global.

12. Evans, "Results and Prospects"; Viotti da Costa, "Experience versus Structures"; French, "The Latin American", and De la Garza Toledo, "Los estudios laborales".

13. González Casanova, Historia del movimiento; Bergquist, Los trabajadores en; Hall and Spalding Jr., "The Urban Working"; Zapata, Autonomía y subordinación; Roxborough, "The Urban Working", and Bethell, Historia de América.

14. In the extensive literature that has addressed this topic, we will only highlight some works with contributions that seem more relevant to our analysis.

H. Spalding defined the AIFLD both as "an ideological arm of the United States and, therefore, of American capitalism in the labor field" and as the "main political arm" of the 
AFL-CIO in their struggle to "promote pro-capitalist oriented unions". Stating that "the study of this organization [the AIFLD] can provide an overall insight into the AFL-CIO's foreign policy", he describes both its education and social projects. Spalding, "Sindicalismo libre: ¿De," 48-58. In an earlier article, the author had already pinpointed the links between the AFL-CIO and the U.S. political and economic power, as well as its influence on ORIT and the different mechanisms employed in several countries - including support for right-wing and anti-labor military dictatorships - where education "comprises the second most important sphere of action after direct methods". Spalding, "U.S. and Latin," 45-69. K. Erickson and P. Peppe emphasized the relationship between AIFLD operations in Chile and Brazil with coups in both countries. Erickson and Peppe, "Dependent Capitalist Development".

In turn, R. Parker has argued that, since World War II, the United States pursued what he viewed as a "systematic policy of un-organizing the Latin American working class". During the cold war years and as part of "a counter-revolutionary policy" reformist efforts, the need for direct indoctrination on the Latin labor movement emerged. To this end, the AIFLD was created, and "from the beginning [it] was an organization staffed and financed by union bureaucrats, representatives of transnational corporations with investments in Latin America and representatives of the US government". Interestingly, Parker describes how the AIFLD operated on sectors deemed as strategic, like communications and farming. Parker, "Imperialismo y organización," 37-61.

Enlightening our topic, J. Basurto Romero has focused on the fierce anti-communist and pro-corporatist contents of AIFLD's educational activities. Basurto Romero, "El sindicalismo y". $\mathrm{N}$. Godfried has written another interesting article on the AFL-CIO's labor education programs in Africa via the actions of the African-American Labor Center (AALC), which proves useful in comparative terms to set U.S. labor imperialism as part of a greater Third World strategy. Godfried, "Spreading American Corporatism". For both favorable descriptions and critical views on AIFLD's performance in Southern Cone countries, see references in footnote 53.

15. The following quote provides a good example: "ORIT, in reality, forms only one link in a vast chain of agencies and organizations that compose the imperialist network seeking to control and manipulate Latin American labor". Spalding, "U.S. and Latin," 52.

16. Such is the case of Spalding, "Sindicalismo libre: ¿De"; Pozzi, "El sindicalismo norteamericano"; Bozza, "Estrategias anticomunistas norteamericanas".

17. Basurto Romero, "El sindicalismo y," 559 .

While commendably detailing the contents used to "educate" the leaders who run the labor unions', this essay mistakenly presents the IIES as an AIFLD creation. Another issue is that the analysis of such contents is not based on an examination of the various courses and seminar programs but on ORIT's publications, mainly their Education Manuals (which were used during classes among many other sources). Finally, another downside is that it gives a static image which does not account for the changes ORIT's educational policy underwent.

18. Basurto Romero, "El sindicalismo y," 586.

19. Walters Jr. and van Goethem, American Labor's Global. However, many of these narratives are elaborated more by interweaving the personal relations existing between the main leaders of the organizations studied, than by an analysis of the collective political programs of such institutions. It should be highlighted that Larissa Corrêa's work focuses on the educational aspect, analyzing the center founded by the AIFLD in Brazil, the Instituto Cultural do Trabalho (ICT); see Corrêa, "'Democracy and Freedom"'.

20. Rodríguez García, Liberal Workers of.

21. Just to cite those who have approached the subject in Latin America, see Saull, "El lugar del", and Brands, Latin America's Cold.

22. Carew, The American Labor.

23. Vergara, "Chilean Workers and," 202.

24. Most authors agree on characterizing them as anti-communists, pro-capitalists, and promoters of capital-labor cooperation.

25. Rodríguez García, Liberal Workers of, 9. This is why she defines their ideology as "labor liberalism".

26. French-Davis, Muñoz and Palma, "The Latin American," 188. 
27. The number of representatives with voting rights each one had was, respectively: seven, seven, three, three, and two, while most countries had just one vote. These data leave aside the United States and Canada, whose organizations represented the bulk of the ICFTU's Regional organization. Information drawn from Rodríguez García, Liberal Workers of, 87.

28. French-Davis, Muñoz and Palma, "The Latin American," 196.

29. Rodríguez García, Liberal Workers of, 85-7 and 198.

30. The change was marked by a decline in the agricultural labor force, the growth of industrial employment, and, primarily, an increase in services and in the informal sector, as well as workforce feminization. Merrick, "The Population of," 38-44.

31. The Economic Commission for Latin America (Comisión Económica para America Latina y el Caribe, ECLA/CEPAL) was influential in this process, regarding both the identification of the causes of underdevelopment and its solutions (modernizing agricultural and industrial sectors and boosting regional commercial integration), as well as insisting on the key role to be played by the State in the resolution of such pitfall. According to Rodríguez García, in matters of economic and social development, ORIT was closer to ECLA's perspective than to the more conservative elements within the U.S. labor movement. Rodríguez García, Liberal Workers of, 172.

32. Over the five years immediately following the end of the war, while the Marshall Plan was implemented for Europe, Latin America only received 2\% of the U.S. overall international aid. This figure grew to $12 \%$ in 1961. Data taken, respectively, from Bethell and Roxborough, "Conclusion: the Postwar," 312-3, and Taffet, Foreign Aid as, 19.

33. Within this barrage of counter-revolutionary measures orchestrated by the $\mathrm{CIA}$, the most remarkable were those implemented in Guatemala (1954), the Bay of Pigs (1961), Brazil (1964), and the Dominican Republic (1965), in addition to its interventionism against radical and progressive labor movement sectors in several South and Central American countries.

34. Starting in 1968, ORIT regretted that the program "is almost paralyzed in the majority of the countries". Organización Regional Interamericana de Trabajadores [ORIT], Noticiario Obrero Interamericano. Year 14, Number 163, March 1968, 1.

35. See Taffet, Foreign Aid as, especially chapter 8.

36. Serafino Romualdi, lecture entitled 'Ideological Origins of the Latin American Union Movement', part of the VIII Course. Cuernavaca, February 28-April 23, 1966, 4. ICFTU Archives - IISH, Folder 5052. Romualdi served as the AFL-CIO Inter-American representative and the first AIFLD director.

37. Roxborough, "The Urban Working," 340-57.

38. On CTAL, see Herrera González, "La Confederación de".

39. Brands, Latin America's Cold, 136.

40. Taffet, Foreign Aid as, 61.

41. Altamirano, "Desarrollo y desarrollistas".

42. International Confederation of Free Trade Unions [ICFTU]. Training the World's Trade Unionists. Brussels: ICFTU, 1956, 93-6.

43. ORIT. Bienvenidos al Instituto de la ORIT-CIOSL. Welcome to the ORIT-ICFTU Labor College. Cuernavaca: ORIT, 1967.

44. Alexander, International Labor Organizations, 137. For more information on the financing for the Institute's site and activities, see Instituto Interamericano de Estudios Sindicales [IIES]. Boletín del Instituto Interamericano de Estudios Sindicales ORIT-CIOSL. Cuernavaca, Year 2, Number 15, July-August 1975, 4.

45. Memo Number 24, signed by Cayetano Pérez (Assistant Director of Education - ORIT), Mexico DF, June 1, 1962. ICFTU Archives - IISH, Folder 5050.

46. Memo Number 53, Mexico DF, November 5, 1962. ICFTU Archives - IISH, Folder 5051.

47. Report of the VI Course for Trade Union Educators, 2. ICFTU Archives - IISH, Folder 5051.

48. Data taken from reports sent by the IIES to ORIT Secretariat. See ICFTU Archives - IISH, Folders 5050 to 5053 , and 5057.

49. American Institute for Free Labor Development [AIFLD]. The AIFLD Report. Washington, DC, Vol. 7, Number 12, December 1969, 2.

50. See the bibliographical references in the second section of this paper. Numerous AFL-CIO leading members served as directors in ORIT's Education Department since 1951, including 
Romualdi, Daniel Benedict, and Morris Paladino. However, it should also be noted that there were differences among them - for example, while Romualdi maintained fluent communications with the CIA, Benedict systematically opposed CIA intervention in the AIFLD. See Vergara, "Chilean Workers and," 208.

51. In this regard, Parker suggests that "In light of ORIT's relative weakness and the inconvenience that some of its members could disagree with the politics proposed by the AFL-CIO, thus hindering a fast and efficient implementation of North American policy, in 1962 a new organization was set up without Latin Americans' engagement". Parker, "Imperialismo y organización," 49.

52. While ORIT's annual budget remained at $\$ 323,000$ between 1962 and 1967, AIFLD's had increased from $\$ 640,000$ to $\$ 4875.000$. Data taken from the United States' State Department, cited in Alexander, International Labor Organizations, 140.

53. For information on the activities and number of AIFLD graduates, see AIFLD. Goal: a Better Mañana. Democratic Labor Schools for the Americas. No editing data, 9. About the Institute, see Alexander, International Labor Organizations; and Romualdi, Presidents and Peons (for an inside narrative). For recent critical studies on AIFLD's actions in the Southern Cone, see: Pozzi, "El sindicalismo norteamericano"; Bozza, "Estrategias anticomunistas norteamericanas"; Vergara, "Chilean Workers and"; and Corrêa, "Democracy and Freedom"'.

54. On relations between ORIT, ICFTU, and AFL-CIO, see Gumbrell-McCormick, "Facing new Challenges".

55. Term coined by John Fitzgerald Kennedy to refer to the process of economic, social, and democratic progress that the Alliance for Progress was supposed to bring to Latin America.

56. While some members felt close to ECLA's ideas, others followed the U.S. modernization theory. But this internal tension was partially solved with the phase opened up by the Kennedy administration since both perspectives converged in ALPRO.

57. ORIT. Manual sobre tareas de educación sindical. Mexico DF: Publicaciones Especiales ORIT-CIOSL, Departamento de Educación y Publicaciones de la ORIT, 1963, 16.

58. To give just one example of a repeated assertion, a report from a Seminar held in 1964 read: "For five years now we have given a great stimulus to socio-economic issues, creating the corresponding Department. Knowledge of social and economic matters is fundamental for today's union movement. Needless to say, understanding and implementing the Alliance for Progress is of utmost significance for all of us." ORIT. Report on the First Seminar of ORIT's Organizers and Representatives. Mexico DF, January 7-10, 1964, 11. ICFTU Archives - IISH, Folder $5057 a$.

It is worth pinpointing that, in general, convergence with ALPRO's objectives occurred due to the existence of shared principles and not because of financing involved in project executions. The argument regarding money received has been largely used to show compliance of Latin unionism to North American plans. In our opinion, this explanation in insufficient since acceptance of such grants says nothing about the real purposes for which these funds were used and particularly because it echoes the image of passive actors already discussed in the historiographical section.

59. Jáuregui's address to the 9th annual meeting of the National Conference on International Social and Economic Development held in Chicago in July 1962. ORIT. Datos y Cifras. Mexico DF, Year VI, Number 31, July-August 1962, 20.

60. Letter from Arturo Jáuregui (ORIT Secretary General) to Omer Becu (ICFTU Secretary General). Brussels, July 5, 1963. ICFTU Archives - IISH, Folder 5058.

61. Letter from Valerio Agostinone (Senior Labor Specialist, Labor Relations Program, Social Affairs Department, Pan American Union - OAS) to Morris Paladino (ORIT Assistant Secretary General). Washington, DC, May 22nd 1963. ICFTU Archives - IISH, Folder 5058.

62. ORIT. Mundo del Trabajo Libre. Mexico DF, Number 193-4, July-August 1966, 16.

63. ORIT. Mundo del Trabajo Libre, Number 207-10, September-December 1967, 13.

64. Cited in Vanguardia de ORIT. Órgano de los participantes del XI Curso del IIES. Cuernavaca, September 1967, Époch I - Number 1, 7. ICFTU Archives - IISH, Folder 5052.

65. ORIT. Noticiario Obrero Interamericano. Mexico DF, Year 16, Number 222, August 1972, 2. 
66. See for example the conclusions of the Forum on the Problem of Employment held in Buenos Aires in late 1972. ORIT would take these recommendations to the next Inter-American Conference of Ministers of Labor to be held in Argentina. ORIT. Datos y Cifras. Mexico DF, Second Epoch, Number 3, January-June 1973, 6-7.

67. ORIT. Manual sobre tareas de educación sindical. Mexico DF: Publicaciones Especiales ORIT-CIOSL, Departamento de Educación y Publicaciones de la ORIT, 1963, 81.

68. We already mentioned echoes of both ECLA and Rostow's modernization theory. Respectively, these groups expressed themselves in the bimonthly Datos y Cifras, and in the monthly official Noticiario Obrero Interamericano.

69. This historical reconstruction is based on the analysis of study programs, reports presented by IIES to ORIT, writings from participants, mimeographed classes, and lists of reading material corresponding to the years 1962-1973. See ICFTU Archives - IISH, Folders 5050 to 5053, and 5057.

70. Report from Mónico Trevizo Marin, member of the Confederation of Mexican Workers and attendee at ORIT IV Course. Chihuahua, November 3, 1963. ICFTU Archives - IISH, Folder 5051.

71. Report from Francisco Gregorio, Juan Carlos de Seta and Héctor Gugliemetti, attendees at IIES IV Course as UNESCO fellows. Attached to letter from Cayetano Pérez (ORIT Assistant Education Director) to Herbert Tulatz (ICFTU Assistant Secretary General), 2. Mexico, March 18, 1964. ICFTU Archives - IISH, Folder 5051.

72. Ibid., 3.

73. ORIT. Memo Number 2, Subject: Inter-American Residential Institute for Labor Studies: Applications for Pilot Program. Mexico DF, January 1962 (original in English). ICFTU Archives - IISH, Folder 5049.

74. This description is based on the III Course (January-March 1963). Although the curriculum underwent small modifications regarding the number of sessions assigned to some subjects or their names, this description summarizes the type of education offered by IIES during its first years.

75. Letter from Raúl Valdivia (ORIT Administrative Head) to Omer Becu (ICFTU Secretary General), Mexico DF, May 4, 1966, with attached Report of VIII Cycle of the Inter-American Institute for Trade Union Education, 1 (original in English). ICFTU Archives - IISH, Folder 5052.

76. Report of the XI Inter-American Course for Trade Union Educators. Cuernavaca, July 28September 12, 1967, 1. ICFTU Archives - IISH, Folder 5052.

77. IIES. 1968 Program Curriculum. Cuernavaca, January 31, 1968. Attached to letter from Arturo Jáuregui (ORIT Secretary General) to Harm Buiter (ICFTU Secretary General). Mexico, February 12 1968. ICFTU Archives - IISH, Folder 5048.

78. Vanguardia de ORIT. Órgano de los participantes del XI Curso del IIES. Cuernavaca, September 1967, Epoch I - Number 1, 3. ICFTU Archives - IISH, Folder 5052.

79. Solidaridad. Vocero del XIV Curso para instructores sindicales del Instituto Interamericano de Estudios Sindicales ORIT/CIOSL. Cuernavaca, June 3, 1968, Year I - Number 1, 7. ICFTU Archives - IISH, Folder 5052.

80. Another of these ordinary specialized courses dealt with 'Problems of Rural and Agricultural Workers' or analyzed 'Workers' Participation in Management'.

81. Report of the XIV Inter-American Course for Trade Union Educators. Cuernavaca, April 18-June 3, 1968, 2. ICFTU Archives - IISH, Folder 5052.

82. With subjects such as: 'The Social and Economic Integration Process in Latin America' and 'Problems of Trade Union Participation in Integration and Development Processes'.

83. Summary based on Courses XV and XIX. See respectively: IIES / International Labor Organization [ILO]. Workers Education Program. XV Ordinary Course Specialized in Development and Integration Issues in Latin America. Cuernavaca, June 3-July 20 1968, 4-8. ICFTU Archives - IISH, Folder 5057b; and IIES. XIX Ordinary Course coordinated with the Inter-American Development Bank on Socio-Economic Development and Integration of Latin America. Cuernavaca, July 17-August 20 1969, ICFTU Archives - IISH, Folder 5053.

84. For example, in 1972 and 1973, courses were centered on: 'Human Resources Development', 'New Methods and Techniques in Workers' Education', 'Trade Union Journalism', and/or 'Labor Economics'. 
85. Although they evolved independently from the Courses for Instructors, IIES bulletin devoted many pages to them.

86. ORIT. Noticiario Obrero Interamericano. Year 14, Number 165, May 1968, 4.

87. ORIT. Noticiario Obrero Interamericano. Suplemento Correo Demográfico. México DF, Year 20, Number 234, January-March 1974, 6.

88. This educational trend was financed by the North American Pathfinder Fund.

89. IIES. Boletín del Instituto Interamericano. Year 1, Number 4/5, January-February 1974, 8.

\section{Disclosure statement}

No potential conflict of interest was reported by the author.

\section{Notes on contributor}

Gabriela Scodeller holds a PhD in History from the University of La Plata, Argentina (2009). She is an assistant researcher of the National Research Council of Argentina (CONICET). She is the author of numerous articles on labor movement and social conflicts in Argentinian's recent history. She is currently studying the educational projects of Latin American labor organizations during the long 1960s.

\section{References}

Alexander, Robert. International Labor Organizations and Organized Labor in Latin America and the Caribbean. A History. Santa Barbara, CA: Praeger, 2009.

Altamirano, Carlos. “Desarrollo y desarrollistas." [Development and Developmentalists] Prismas. Revista de historia intelectual, 2, no. 2 (1998): 75-94.

Basurto Romero, Jorge. “El sindicalismo y la penetración ideológica de los Estados Unidos en América Latina." [Trade Unionism and the Ideological Penetration of the United States in Latin America] Revista Mexicana de Sociología 34, no. 3/4 (1972): 551-594.

Bergquist, Charles. Labor in Latin America: Comparative Essays on Chile, Argentina, Venezuela and Colombia. Stanford: Stanford University Press, 1986.

Bethell, Leslie (ed.). The Cambridge History of Latin America. 12 vols. Cambridge: Cambridge University Press, 1984-1995.

Bethell, Leslie, and lan Roxborough. "Conclusion: The Postwar Conjuncture in Latin America and its Consequences." In Latin America Between the Second World War and the Cold War, 1944-1948, edited by Leslie Bethell and lan Roxborough, 327-334. New York: Cambridge University Press, 1992.

Bozza, Juan Alberto. "Estrategias anticomunistas norteamericanas frente a la radicalización sindical en Argentina y Chile (1962-1973)." [North American Anti-communist Strategies against Labor Radicalization in Argentina and Chile (1962-1973)] PolHis. Boletín bibliográfico electrónico del programa de Buenos Aires de historia política 5, no. 10 (2012): 197-210.

Brands, Hal. Latin America's Cold War. Cambridge: Harvard University Press, 2010.

Carew, Anthony. "The American Labor Movement in Fizzland: The Free Trade Union Committee and the CIA." Labor History 39, no. 1 (1998): 25-42.

Carew, Anthony, Michel Dreyfus, Geert van Goethem, Rebecca Gumbrell-McCormick, and Marcel van der Linden, eds. The International Confederation of Free Trade Unions. Bern: Peter Lang, 2000.

Corrêa, Larissa. "'Democracy and Freedom' in Brazilian Trade Unionism during the Civil Military Dictatorship: the Activities of the American Institute for Free Labor Development."In American Labor's Global Ambassadors. The International History of the AFL-CIO During the Cold War, edited by Robert Anthony Walters Jr., and Geert van Goethem, 177-199. New York: Palgrave, 2013.

De la Garza Toledo, Enrique. "Los estudios laborales en América Latina al inicio del siglo XXI." [Labor Studies in Latin America at the Beginning of the Twenty First Century] Sociología del Trabajo Nueva época, no. 61 (2007): 125-165. 
Erickson, Kenneth, and Patrick Peppe. "Dependent Capitalist Development, U.S. Foreign Policy, and Repression of the Working Class in Chile and Brazil." Latin American Perspectives 3, no. 1 (1976): 19-44.

Evans, Judith. "Results and Prospects: Some Observations on Latin American Labor Studies." International Labor and Working Class History 16 (1979): 29-39.

French, John. "The Latin American Labor Studies Boom." International Review of Social History 45 (2000): 279-308.

French-Davis, Ricardo, Oscar Muñoz, and José Gabriel Palma. "The Latin American Economies, 1950-1990." In The Cambridge History of Latin America, edited by Leslie Bethell, Vol. 6/1, 159-250. Cambridge: Cambridge University Press, 1995.

Godfried, Nathan. "Spreading American corporatism: trade union education for third world labour." Review of African Political Economy 39 (1987): 51-63.

Godio, Julio, and Achim Wachendorfer. “Las internacionales sindicales." Nueva Sociedad [International Confederations] 83 (1986): 81-88.

González Casanova, Pablo, ed. Historia del movimiento obrero en América Latina [History of the Labor Movement in Latin America]. 4 vols. México: S. XXI, 1984.

Gumbrell-McCormick, Rebecca. "Facing New Challenges: The International Confederation of Free Trade Unions (1972-1990s)." In The International Confederation of Free Trade Unions, edited by Anthony Carew, Michel Dreyfus, Geert van Goethem, Rebecca Gumbrell-McCormick and Marcel van der Linden, 341-517. Bern: Peter Lang, 2000.

Hall, Michael, and Hobart Spalding Jr. "The Urban Working Class and Early Latin American Labour Movements, 1880-1930." In The Cambridge History of Latin America, edited by Leslie Bethell, Vol. 4, 325-366. Cambridge: Cambridge University Press, 1986.

Heerma van Voss, Lex, Patrick Pasture, and Jan De Maeyer, eds. Between Cross and Class: Comparative Histories of Christian Labour in Europe 1840-2000. Bern: Peter Lang, 2005.

Herrera González, Patricio. “La Confederación de Trabajadores de América Latina. Una historia por (re)significar (1938-1963)." [The Confederation of Latin American Workers. A Story to (re) Signify] Secuencia. Revista de historia y ciencias sociales 86 (2013): 193-218.

Mergner, Gottfried. Social Limits to Learning. Essays on the Archeology of Domination, Resistance and Experience. New York: Berghahn Books, 2005.

Merrick, Thomas. "The population of Latin America, 1930-1990." In The Cambridge History of Latin America, edited by Leslie Bethell, Vol. 6/1, 1-62. Cambridge: Cambridge University Press, 1995.

Parcero, Daniel. La CGT y el sindicalismo latinoamericano. Historia critica de sus relaciones desde el ATLAS a la CIOSL [The CGT and Latin American unionism. A Critical History of its Relations from the ATLAS to the ICFTU]. Buenos Aires: Editorial Fraterna, 1987.

Parker, Richard. "Imperialismo y organización obrera en América Latina." [Imperialism and Workers Organization in Latin America] Cuadernos Políticos 26 (1980): 37-61.

Piaget, Jean. La toma de conciencia [The Grasp of Consciousness]. Madrid: Morata, 1976.

Pozzi, Pablo. "El sindicalismo norteamericano en América Latina y en la Argentina: el AIFLD entre 1961-1976." [North American Unionism in Latin America and in Argentina: the AIFLD between 1961-1976] Revista Herramienta 10 (1999): 163-184.

Rodríguez García, Magaly. Liberal Workers of the World, Unite? The ICFTU and the Defense of Labour Liberalism in Europe and Latin America (1949-1969). Bern: Peter Lang, 2010.

Romualdi, Serafino. Presidents and Peons. Recollections of a Labor Ambassador in Latin America. New York: Funk \& Wagnalls, 1967.

Roxborough, lan. "The Urban Working Class and Labour Movement in Latin America since 1930."In The Cambridge History of Latin America, edited by Leslie Bethell, Vol. 6/2, 305-378. Cambridge: Cambridge University Press, 1995.

Saull, Richard. "El lugar del sur global en la conceptualización de la guerra fría: desarrollo capitalista, revolución social y conflicto geopolítico." In Espejos de la Guerra Fría: México, América Central y el Caribe ["The Place of the Global South in the Conceptualization of the Cold War: Capitalist Development, Social Revolution and Geo-political Conflict." In Mirrows of the Cold War: Mexico, Central America and the Caribbean], edited by Daniela Spenser, 31-66. México: Porrúa, 2004. 
Spalding, Hobart."Sindicalismo libre: ¿De qué? El instituto Americano para el desarrollo del sindicalismo libre." [Free Trade Unionism: Of What? The American Institute for Free Labor Development] Revista Nueva Sociedad 70 (1984): 48-58.

Spalding, Hobart. “U.S. and Latin American Labor: the Dynamics of Imperialist Control." Latin American Perspectives 3, no. 1 (1976): 45-69.

Taffet, Jeffrey. Foreign Aid as Foreign Policy. The Alliance for Progress in Latin America. New York: Routledge, 2007.

Van Daele, Jasmine, Magaly Rodríguez García, Geert van Goethem, and Marcel van der Linden, eds. ILO Histories. Essays on the International Labour Organization and its Impact on the World during the Twentieth Century. Bern: Peter Lang, 2010.

Vergara, Angela. "Chilean Workers and the US Labor Movement: From Solidarity to Intervention, 1950s-1970s." In American Labor's Global Ambassadors. The International History of the AFL-CIO during the Cold War, edited by Robert Anthony Walters Jr., and Geert van Goethem, 201-214. New York: Palgrave, 2013.

Viotti da Costa, Emilia. "Experience versus Structures: New Tendencies in the History of Labor and the Working Class in Latin America. What Do We Gain? What Do We Lose?" International Labor and Working Class History 36 (1989): 3-24.

Walters, Robert Jr., and Geert van Goethem, eds. American Labor's Global Ambassadors. The International History of the AFL-CIO during the Cold War. New York: Palgrave, 2013.

Zapata, Francisco. Autonomía y subordinación en el sindicalismo latinoamericano [Autonomy and Subordination in Latin American Unionism]. México: Fondo de Cultura Económica, 1993. 